\title{
Macronutrient Analysis Of Crab Meat Analogue Made From Non- Consumable Fish With Alginate Addition
}

\author{
Ellya Sinurat, Singgih Wibowo,Dina Fransiska \\ Research and Development Center for Marine and Fisheries Product Processing and \\ Biotechnology, Ministry of Marine and Fisheries
}

\begin{abstract}
Abstrak
Produk analog daging kepiting menggunakan alginat dan protein seperti kedelai. Campuran ikan ditambah dengan alginat yang diikat silang dengan gel pembuatan kalsium klorida dan retensi air. Tujuan penelitian ini adalah untuk mempelajari analisis makronutrien dari efek penambahan alginat terhadap karakteristik analog daging kepiting. Formulasi dibuat dari kombinasi alginat dari Sargassum sp. Formulasi tersebut diaplikasikan pada surimi dari ikan kapasan (Gerres Kapas Blkr) untuk membuat daging kepiting analog dengan konsentrasi yang berbeda $(0,25 \%, 0,5 \%, 0,75 \%, 1 \%)$. Parameter yang digunakan untuk mempelajari efeknya adalah kadar air, abu total, kadar protein, kadar lemak, nilai asam tiobarbiturat dan evaluasi sensoris. Analisis kimia, kadar air, dan analisis kadar abu menunjukkan perbedaan yang signifikan di antara perlakuan, sedangkan nilai asam tiobarbiturat tidak menunjukkan perbedaan diantara sampel. Berdasarkan evaluasi sensorik, produk yang paling disukai adalah formula $\mathrm{A}$ (alginat $0,25 \%$ ) dalam hal tekstur, rasa, kebasahan, dan penerimaan secara keseluruhan dengan karakteristik kadar abu 2,47\%, kadar air 75,98\%, kadar lemak 0,47\%, kandungan protein $12,7 \%$, nilai asam tiobarbiturat $0,69 \mu \mathrm{mol} / \mathrm{g}$.
\end{abstract}

Kata kunci: analog daging kepiting, alginat, makronutrien, non-konsumsi, Sargassum sp.

\begin{abstract}
The crab meat analogue products using alginates and proteins such as soybean. A mixture of fish added alginate croslinking with calcium chloride making gel and water retention. The purpose of this study to analysis macronutrient from the effects of alginate addition to the characteristics of the crab meat analogue. The formulation was made from the combination of alginate from Sargassum sp. The formulation was applied to the surimi from silver giddy (Gerres Kapas Blkr) to make crab meat analogue with different concentrations $(0.25 \%, 0.5 \%, 0.75 \%, 1 \%)$. Parameters used to study the effects were moisture content, total ash, protein content, fat content, thiobarbituric acid value and sensory evaluation. The chemical analysis, moisture content, and ash content analysis showed a significant difference among the treatments, while the thiobarbituric acid value showed no difference among the samples. Based on sensory evaluation, the most preferred product was formula A $(0.25 \%$ alginate $)$ in terms of texture, taste, juiciness and overall acceptance with the characteristics of $2.47 \%$ ash content, $75.98 \%$ moisture content, $0.47 \%$ fat content, $12.07 \%$ protein content, thiobarbituric acid value of $0.69 \mu \mathrm{mol} / \mathrm{g}$.
\end{abstract}

Keyword : crab meat analog, alginate, macronutrient, non consumable, Sargassum sp. 


\section{Introduction}

The various meat products, such as sausages, surimi-based foods, crab meat analogue, and meat-fried fish paste in the past few decades have been developed. ${ }^{[1]}$ Non consumable fish are included as low economical fish, which means that they have a low market value and the utilization for food processing is low because the taste of the meat is not as good as stingray and swordfish. Another disadvantage is that non-consumable fish has a short shelf life due to fast decomposition when not stored in frozen condition. Non-consumable fish are small fish with the size of $\pm 10 \mathrm{~cm}$ that are accidentally caught by fishermen and are sold in low price. The types of fish that fit these criteria are kuniran, rebon, kurisi, and tembang. ${ }^{[2]}$

According to Lages et al. ${ }^{[3]}$, the utilization of trash fish is limited to traditional uses only, such as the manufacture of salted fish, fish crackers, and fish sauce. The utilization of non-consumable fish other food products is actually possible along with the development of technology. Silver Biddy Fish (Gerres Kapas Blkr) are small fish that generally lives in tropical waters. This kind of fish is considered as trash fish due to its small size and low price. They are pelagic fish that search for food on the surface and are easily found near the shore or areas where the water is shallow. The shape of the body is flat and straight, silver in color, and the whole body is covered with scales. The mouth can protrude to the bottom and it has long and sharp fins. Its unique characteristic is the shape of the head which is raised when its mouth is closed. Its fish scales are relatively large and even the head is covered with scales. ${ }^{[4]}$

Generally crab meat analogue making from the best surimi product. This research using non-consumable fish added alginate, because alginate ability to water retention on surimi. Water retention ability can be to determine the effects of setting on the gel functionalities. ${ }^{[5]}$ The term "alginate" is used commonly for the salts of alginic acid, but the term can also mean the derivatives of alginic acid and alginic acid itself. ${ }^{[6]}$

The various kinds of alginate salts include the sodium, potassium, ammonium, and calcium salts. However, according to $\mathrm{McHugh}^{[7]}$ the most important alginate salt for industries is the alginate salt, which is sodium alginate. Alginate is a hydrocolloid that is present in the intercellular matrix as the most abundant polysaccharide in brown algae. ${ }^{[8]}$ The biological function of alginate in brown algae is as a structure-forming component that provides the mechanical strength and flexibility of the seaweed and also act as water reservoir that prevents dehydration when the seaweed exposed to air. $^{[9]}$

Alginates that are contained in different algae or even in different tissue of the same algae have different properties. For example, the alginate that is contained in Laminaria hyperborea have a very high content of guluronic acid which gives mechanical rigidity; while in the leaves of the same algae, the alginate has a lower guluronic acid content which gives a more flexible form. ${ }^{[8]}$ A high-quality of alginate forms to make strong gel and give thick aqueous solutions. A good raw material for alginate extraction should also give a high yield of alginate. ${ }^{[6]}$

The objective of this research is to study analysis macronutrient the effects of applying alginate extracted from Sargassum $\mathrm{sp}$. to crab meat analogue made from silver biddy fish. The application of alginate made from brown seaweeds available in Indonesia is hoped to increase the production and application of alginate. The use of silver biddy fish is hoped to increase the economic value of the fish itself.

\section{Materials and Method}

Materials

The main raw materials used in this research are sodium alginate extracted from Sargassum sp. and Turbinaria sp. which are harvested from the Binuangeun region, West Java. The extraction of alginate was 
done in Research Center and Development for Marine and Fisheries Product Processing and Biotechnology, Jakarta using the method developed by Murdinah et al. with minor modifications. The modification was the addition of $\mathrm{NaOCl}$ which was reduced from $4 \%$ to $2.5 \%$. Another important raw material in this research is the surimi. The surimi that is used to make crab meat analogue is made from silver biddy fish fillet that was bought from a filetting factory in Batang. The method for making surimi was based on the method described by Anggawati and Indriati. ${ }^{[10]}$ Other ingredients used for making crab meat analogue was cassava starch, sugar, salt, crab flavour, egg white, calcium carbonate $(\mathrm{CaCO} 3)$, soybean oil, sodium tripolyphosphate (STPP), monosodium glutamate (MSG), and cooked crab meat bought from a factory in Batang, these ingredients food grade were bought in Harum Sari (Jakarta).
Method

The procedure for making crab meat analogue, the first process involved the mixing of salt and STPP with surimi in a meat processor for about 30 seconds until a sol was created. The next step was the addition of starch, sugar, MSG, alginate, calcium carbonate, flavour, egg white, and vegetable oil. The mixture was mixed again for 1-2 minutes. The very long processing time was avoided to keep the freshness of surimi. The mixture was then put into a mold and covered with aluminium foil. Then, it was heated in $60^{\circ} \mathrm{C}$ waterbath for 20 minutes and was moved to a steam cooker and heated for 10 minutes. After finished, it was then cooled, added lightly with color on the surface, and cut. The color solution consisted of $0.25 \%$ red scarlet (Ponceau 4R), $0.25 \%$ orange (Allura red AC) and 1\% alginate. The percentage alginate applied was $0.25 \%, 0.5 \%, 0.75 \%$, and $1 \%$. The treatments were compared with a control positive and negative; the control positive

Table 1 Formula of Crab Meat Analogue Using Alginate

\begin{tabular}{lllllll}
\hline \multirow{2}{*}{ Ingredients } & \multicolumn{2}{l}{ Formula } & \multicolumn{2}{l}{} \\
\cline { 2 - 7 } & Control (-) & Control (+) & $\mathbf{A}$ & $\mathbf{B}$ & $\mathbf{C}$ & $\mathbf{D}$ \\
\hline Surimi & 90.63 & 89.17 & 90.38 & 90.13 & 89.88 & 89.63 \\
Tapioca starch & 5.28 & 5.28 & 5.28 & 5.28 & 5.28 & 5.28 \\
Sugar & 1.4 & 1.4 & 1.4 & 1.4 & 1.4 & 1.4 \\
Salt & 0.5 & 0.5 & 0.5 & 0.5 & 0.5 & 0.5 \\
Crab flavor & 0.29 & 0.29 & 0.29 & 0.29 & 0.29 & 0.29 \\
Alginate & 0 & 0.25 & 0.25 & 0.5 & 0.75 & 1.0 \\
White Egg & 0.41 & 0.41 & 0.41 & 0.41 & 0.41 & 0.41 \\
CaCO3 & 0.66 & 0.66 & 0.66 & 0.66 & 0.66 & 0.66 \\
Soybean oil & 0.33 & 0.33 & 0.33 & 0.33 & 0.33 & 0.33 \\
STPP & 0.2 & 0.2 & 0.2 & 0.2 & 0.2 & 0.2 \\
MSG & 0.3 & 0.3 & 0.3 & 0.3 & 0.3 & 0.3 \\
Crab meat & 0 & 1.46 & 0 & 0 & 0 & 0 \\
Total & 100 & 100 & 100 & 100 & 100 & 100
\end{tabular}

Remarks: Control (-): the formulation without the addition of alginate,

Control (+): the formulation addition of real crab meat

Formula A, B, C, and D refers to addition alginate $(0.25 \%, 0.5 \%, 0.75 \%$, and $1 \%)$ 
being the crab meat analogue without alginate but with the addition of real crab meat and the control negative being the crab meat analogue without the addition of alginate.

Characteristic macronutrient of crab meat include chemical analysis and sensory evaluation.

Chemical Analysis at list of water content (SNI 01-2354.2-2006), fat content (SNI SNI 01-2354.3-2006), Protein content (SNI 01-2354.4-2006), Total Ash Content (SNI 01-2354.1-2010), Thiobarbituric Acid Value (Lemon, 1975).

Sensory Evaluation

The type of organoleptic test used in this research was hedonic test to evaluate the preference of each treatment of crab meat analogue. The parameters for hedonic test include color, aroma, taste, texture, juiciness, and overall acceptance. The scale used for hedonic test is a 7-point scale, in which 1 reflects extreme dislike and 7 reflects extreme likeness.

Data analysis for chemical and physical analysis was done using one, two, or threeway ANOVA (analysis of Variance) in Open Stat software with $95 \%$ confidence level. Post hoc analysis was done using using Tukey HSD (Honesty Significant Difference). Sensory test was analysed using two-way ANOVA without replication in Data Analysis in Microsoft Excel with 95\% confidence level. The t-test between samples for means was done to the parameters that showed significant difference.

\section{Result and Discussion}

Chemical Characteristics Crab Meat Analogue

Chemical characteristics are important to be analyzed because they are the basis of texture as well as taste of the product. The analyses conducted include moisture content, total ash content and TBA value. The chemical characteristics of crab meat analogue are tabulated in Table 5.

\section{Moisture Content}

Water is an essential substance of human life. Water is the most important part in food because it affects texture, appearance and taste of food product. ${ }^{[1]}$

The principle of moisture content measurement is the difference in weight before and after the sample was dried in the oven. Moisture content was represented in percentage. The results of moisture content in this experiment was between $74.18 \%$ $76.09 \%$. The data showed significant difference when statistical analysis was done using One, Two or Three-Way ANOVA with $95 \%$ confidence level. The Tukey HSD test showed that formula A and B showed no

Table 2. Chemical characteristic of Crab Meat Analogue

\begin{tabular}{lccccc}
\hline \multicolumn{1}{c}{ Parameters } & $\begin{array}{c}\text { Moisture } \\
\text { content }(\mathbf{\%})\end{array}$ & $\begin{array}{c}\text { Ash content } \\
(\mathbf{\%})\end{array}$ & $\begin{array}{c}\text { Protein } \\
\text { content }(\mathbf{\%})\end{array}$ & $\begin{array}{c}\text { Fat content } \\
(\mathbf{\%})\end{array}$ & $\begin{array}{c}\text { TBA value } \\
(\boldsymbol{\mu m o l ~ M A / g})\end{array}$ \\
\hline Control (-) & $76.09 \pm 0.23$ & $2.19 \pm 0.05$ & $12.16 \pm 0.10$ & $0.84 \pm 0.01$ & $0.64 \pm 0.03$ \\
Control (+) & $75.19 \pm 0.12$ & $2.40 \pm 0.00$ & $12.07 \pm 0.12$ & $0.47 \pm 0.01$ & $0.69 \pm 0.01$ \\
A & $75.98 \pm 0.10$ & $2.32 \pm 0.02$ & $11.82 \pm 0.09$ & $0.37 \pm 0.01$ & $0.69 \pm 0.05$ \\
B & $75.47 \pm 0.32$ & $2.35 \pm 0.02$ & $11.51 \pm 0.11$ & $0.33 \pm 0.01$ & $0.63 \pm 0.04$ \\
C & $74.40 \pm 0.09$ & $2.47 \pm 0.06$ & $11.21 \pm 0.10$ & $0.32 \pm 0.01$ & $0.62 \pm 0.04$ \\
D & $74.18 \pm 0.58$ & $2.52 \pm 0.07$ & $10.98 \pm 0.09$ & $0.29 \pm 0.00$ & $0.58 \pm 0.01$
\end{tabular}

Remarks: Control (-): the formulation without the addition of alginate, Control (+): the formulation addition of real crab meat Formula A, B, C, and D refers to addition alginate $(0.25 \%, 0.5 \%, 0.75 \%$, and $1 \%)$ 
difference to negative and positive control in terms of water content. On the other hand, Formula $\mathrm{C}$ and $\mathrm{D}$ showed significant difference with the controls and formula $\mathrm{B}$ and $\mathrm{A}$, but no significant difference among each other and resulted in low moisture content, which were $74.40 \pm 0.09 \%$ and $74.18 \pm 0.58 \%$ respectively.

The ash content resulted that the ash content of the crab meat analogue ranged from $2.19 \%-2.52 \%$. The result proved that there were significant differences between the samples. The highest ash content was obtained from formula $\mathrm{D}$, while the lowest ash content was obtained from the negative control formula with no significant difference from the other formulas. From the Tukey HSD test, the negative control was significantly different with the others and showed the least value of ash content. Formula A and B showed insignificant difference between each other but are significantly different with the others. Finally, the positive control, formula C, and formula $\mathrm{D}$ are considered to be the group with the highest ash content which are insignificantly different with each other, but showed a significant difference with the others.

\section{Protein content}

The protein content resulted of the crab meat analogue ranged from 10.98\% - 11.82\%. Statistical analysis was done using One, Two or Three-Way ANOVA with 95\% confidence level. The higest alginate concentrate resulted low protein concentrate. Finally, the positive control, formula $\mathrm{C}$, and formula $\mathrm{D}$ are considered to be the group with the low protein content which are insignificantly different with each other, but showed a significant difference with the others.

\section{Fat content}

The resulted of fat content from the crab meat analogue ranged from $0.29 \%$ $0.37 \%$. The similarity with protein content resulting that the highest alginate consentrate to result low fat content. Formula without alginate to result high fat content compare with applied of alginate.

\section{TBA Value}

Thiobarbituric acid (TBA) value is a measure of auto-oxidation of lipid in food product. Lipids can be easily oxidized in the presence of catalytic systems such as light, heat, enzymes, metals, metalloproteins, and microorganisms. ${ }^{[12]}$ This lipid oxidation may give rise to the development of offflavor and loss of essential nutrients. TBA value is measured by spectroscopy. The principle of this method is reaction of malonaldehyde with TBA molecules to form malonaldehyde-TBA complex and form pink color, in which the absorbance can be measured by using spectrophotometer at 540nm. ${ }^{[13]}$ Malonaldehyde is a secondary product of oxidation which is formed as a result of degradation of polyunsaturated fat. ${ }^{[12]}$ Malonaldehyde is extracted from the sample by using the extraction solution. The sample was filtered and the solution was taken to be reacted with TBA, heated, and measured its absorbance. The average range of TBA value in the crab meat analogue was $0.58 \%-0.69 \%$. The statistical result using One, Two or Three-Way ANOVA with 95\% confidence level resulted in high p-value (0.11) which showed that there was no significant difference in TBA value among each sample. This was probably because the addition of alginate was still at a small range.

\section{Sensory Evaluation}

Hedonic test was done to evaluate the preference of panelists towards the product. The parameters for hedonic test were color, odor, texture, taste, juiciness, and overall preference as show as at Table 3.

The average score for the color of imitation meat made from silver giddy fish was ranged from 4.75 to 5.56 . This means that the judgement of the panelists to the color of crab meat analogue made from silver giddy fish was between "like slightly" 
to "very like". Panelists prefered to formula $\mathrm{A}(0,25 \%$ alginate $)$ with value 6.56 it is mean very like. The statistical analysis showed that there was no significant difference between the samples in terms of color. This happened because the samples were given the same coloring, which contribute to the similarity in color preference among the samples. The perception of people towards the color of food products is important for the market of the product. If the color of the product did not meet their expectation, they would not buy that particular product.

The average score for the odor of imitation meat made from silver giddy fish was ranged from 4.13 to 4.69 , which means that the panelists' preference for odor ranged from "like slightly" to "like". The statistical analysis resulted in insignificance among each sample. This was expected because the alginate used in this product was odorless and may not contribute to the odor of the crab meat analogue. However, one panelist commented that the positive control contained a trace of fishy odor. This may occur because the positive control contained natural crab meat which may have given the slight fishy odor. Odor is also one of the crucial factors in a product because it can also influence the taste of the food. In general, the smell that could be sensed by the nose and brain includes a mixture of odors, which are fragrant, sour, rancid, and the smell of charred. ${ }^{[11]}$

Result of sensory evaluation for texture showed that the average hedonic score for texture is in the range between 3.35 and 5.44. This means that the texture of the crab meat analogue is between the criteria "slightly dislike" and "like". The statistical analysis done using Two-Factor ANOVA Without Replication and showed a significant difference in at least one of the sample. The highest average score was given to the negative control, while the least average score was given to Formula $\mathrm{C}$ with $0.75 \%$ addition of alginate. A series of t-tests were done and showed that the hedonic score for formula $\mathrm{C}$ is the least preferred and is significantly different with other samples. The second group of samples that received the mediate score consists of formula B and D. The most preferred samples were the negative control, positive control, and formula $\mathrm{A}$ and showed no significant difference among each other, but are proven to be significantly different with the others. It can be concluded that formula $\mathrm{A}$ is similarly preferred as the control positive samples. The comments from the panelists stated that formula $\mathrm{C}$ and $\mathrm{D}$ were too soft. The panelists also wrote that the texture for formula $\mathrm{B}$ was too rough and less elastic. The comment for the lack of elasticity was also received by formula A. The rough and less elastic texture in the addition of alginate confirms the theory by Suzuki ${ }^{[14]}$ which said that alginate causes brittleness and loss of elasticity in surimi gels. However, Prawira ${ }^{[11]}$ was able to prove

Table 3. Result of Sensory Evaluation Score Crab Meat Analogue.

\begin{tabular}{lllllll}
\hline \multirow{2}{*}{ Formula } & \multicolumn{7}{c}{ Parameters } \\
\cline { 2 - 7 } & Colour & Odor & Texture & Taste & Juiciness & $\begin{array}{l}\text { Overall } \\
\text { acceptance }\end{array}$ \\
\cline { 2 - 7 } & 5.44 & 4.38 & 5.44 & 5.50 & 5.25 & 5.25 \\
Control (-) & 5.13 & 4.69 & 5.19 & 5.19 & 4.94 & 5.25 \\
Control (+) & 5.56 & 4.69 & 5.25 & 5.00 & 5.00 & 5.25 \\
A & 4.75 & 4.13 & 3.94 & 4.44 & 4.13 & 4.19 \\
B & 4.94 & 4.50 & 3.06 & 4.13 & 3.81 & 3.69 \\
C & 5.13 & 4.56 & 3.25 & 4.44 & 3.75 & 3.69 \\
D & & & & &
\end{tabular}


that the addition of alginate up to $0.75 \%$ in kamaboko made from cork fish was able to increase the gel strength of alginate as well as the hedonic score for texture. From this statement, it may be concluded that the addition of alginate by itself, without the addition of other ingredients, may be able to increase these characteristics. In the production of crab meat analogue, there may be interactions between alginate and other ingredients.

Result of analysis sensory evaluation for taste showed that the average score for the taste of the crab meat analogue was 4.135.50, which was in the range between "like slightly" and "very like". The statistical analysis proved that there was at least one data that was significantly different to the other samples. The negative control was the most preferred in terms of taste. However, the series of t-tests showed that the negative control, positive control, and formula A were insignificantly different. From this result, it can be concluded that formula A closely resembles the controls and the addition of $0.25 \%$ showed insignificant difference in taste. Furthermore, the second group, which consisted of formula $\mathrm{B}$ and $\mathrm{D}$ was give mediate score; while formula $\mathrm{C}$ was given the lowest score in terms of taste. This result showed that texture affected the acceptance of panelists in terms of taste. According to Tournier et al., the recent studies agreed that the texture influences a flavor perception and an increase in hydrocolloids concentration generally caused a decrease in aroma and taste perception. The decreasing score for texture with the increase in alginate may have confirmed this theory.

Result of analysis sensory for juiceness showed that the average score for juiciness showed a range of $3.75-5.25$, which was in the range between "dislike slightly" and "very like". The statistical analysis showed the significant difference in at least one of the samples. The highest average score was given to the negative control, while the lowest average score was given to formula D. generally, the juiciness score tends to decrease with increasing alginate concentration. Alginate, which is a hydrocolloid, has a strong water-binding property that may contribute to juiciness. ${ }^{[15]}$ However, the increasing addition of alginate in crab meat analogue made from silver giddy fish showed a decrease in juiciness. This may happen because the texture score also decreased. juárez et al. ${ }^{[16]}$ stated that there is a correlation between texture and juiciness. The preference of juiciness from the panelists may have decreased because of the decrease in preference of texture. Juiciness is considered to arise from the moisture that is released from the meat during chewing. Juiciness is influenced by fat content and also physiological and psychological factors related to the panelists. $^{[16]}$

The panelists' average score of overall acceptance showed that the range of preference was between 3.69 and 5.25, which was between "dislike slightly" and "very like". The result of statistical analysis showed that there were significant differences between the preferences of the crab meat analogue. The lowest average score was given to formula $\mathrm{C}$ and $\mathrm{D}$, which was also insignificantly different to formula B. The best scores were equally given to both control formulas and also formula A. From this data, it can be concluded that the preference of panelists for formula A (0.25\% alginate addition) was similar to the preference for the control formulas, which was between "like" and very like". The best scores productbased on panelist, if compared to crab meat commercial protein content not significantly different about $15.8 \%$, because added value from surimi product is protein content. Based on result that alginate ability to retention water of crab meat analogue. An ionic crosslinking always involves an ion-exchange process. ${ }^{[8]}$ The starting point is a water-soluble sodium alginate, when $\mathrm{Ca} 2+$ ion is present, there will be an exchange of ions, which gives a sol/gel transition. Because of the very rapid and irreversible cross linking between 
alginates and ions, it is difficult to obtain a homogeneous gel without applying high shear and adding low molecular alginate along with low amounts of ion. There are many purposes for applying alginate to form gel. Therefore, the technique in which the crosslinking ions are introduced into the alginate mixture is also important. The two methods of introducing the ions into the alginate mixture are diffusion setting and internal setting. ${ }^{[8]}$

\section{Conclusions}

The silver biddy fish could be applied in the production of crab meat analogue based on sensory evaluation, the most preferred product was $0.25 \%$ alginate addition in terms of texture, taste, juiciness and overall acceptance with the characteristics of $2.32 \pm$ $0.02 \%$ ash content, $75.98 \pm 0.01 \%$ moisture content, $11.87 \pm 0.09 \%$ protein content, $0.47 \pm 0.01 \%$ fat content, thiobarbituric acid value of $0.69 \mu \mathrm{mol} / \mathrm{g}$, hardness $3777.30 \mathrm{~g} /$ $\mathrm{cm} 2$, and cohesiveness 0.26 .

\section{References}

[1] Jin Sang Keun, Jung Seok Choi , Yeung Joon Choi, Seung-Jae Lee , Seung Yun Lee, and Sun Jin Hu. Antioxidant, Liver Protective and Angiotensin I-converting Enzyme Inhibitory Activities of Old Laying Hen Hydrolysate in Crab Meat Analogue. Asian Australas. J. Anim. Sci. 2016; Vol. 29, No. 12: 1774-1781

[2] Koesoemawardani, D. \& N. Fibra. Kajian Hidrolisat Protein Dari Ikan Rucah Sebagai Bahan Fortifikasi Makanan (Study of Hydrolisates Protein of Trash Fish as Food Fortification Material). Lampung: Universitas Lampung. 2009.

[3] Lages, A.C., D. Apriyani, D.S. Agustina. Konsentrat Kalsium Tinggi dari Ikan Rucah Sebagai Bahan Tambahan untuk Permen Berkalsium [Bachelor"s Thesis]. Bogor: Fakultas Perikanan dan Ilmu Kelautan, Institut Pertanian Bogor. 2011.
[4] Suryawan, A. G. Karakteristik Mutu Ikan Selama Penanganan Oleh Nelayan Tradisional Dengan Jaring Rampus (Studi Kasus di Kaliadem, Muara Angke, DKI Jakarta). [Bachelor's Thesis]. Bogor: Fakultas Perikanan dan Ilmu Kelautan, Institut Pertanian Bogor. 2004.

[5] Kim, S.M., Surimi-alginate gels as affected by setting: a study based on mixture design and regression models., Food Research International J, 2009; 36: 295-302

[6] McHugh, D.J. "Alginate" in A guide to the Seaweed Industry; FAO Fisheries Technical Paper, No. 441. Rome: Food and Agriculture Organization. 2003.

[7] McHugh, D.J. (ed.). Production and utilization of products from commercial seaweeds. FAO Fisheries Technical Paper, No.288. Rome: Food and Agriculture Organization. 1987.

[8] Draget, K.I. “Alginates" in Handbook of Hydrocolloids 2nd ed. Woodhead Publishing Limited, UK. 2009.

[9] Donati I. \& S. Paoletti. Material Properties of Alginates. in Alginates: Biology and Applications ed. by B.H.A. Rehm. Microbiology Monographs J. 2009; 13: 1-46, Springer, Germany.

[10] Anggawati, A. M. \& N. Indriati. Surimi in Kumpulan Hasil-Hasil Penelitian Pascapanen Perikanan (ed. revisi) J 2011; 269-274, Balai Besar Penelitian dan Pengembangan Pengolahan Produk dan Bioteknologi Kelautan dan Perikanan, Jakarta.

[11] Prawira, A. Pengaruh Penambahan Tepung Alginat (Na-alginat) Terhadap Mutu Kamaboko Berbahan Dasar Surimi Ikan Gabus (Channa striata) [Bachelor's Thesis]. Bogor: Fakultas Perikanan dan Ilmu Kelautan. Institut Pertanan Bogor. 2008.

[12] Shahidi, F., Y.Zhong. Lipid Oxidation: Measurement Methods in Bailey's Industrial Oil and Fat Products Ed. F. 
Shahidi 2005; 1(6): 357-385, Wiley Interscience.

[13] Tokur, B., K. Korkmaz, D. Ayas. Comparison of Two Thiobarbituric Acid (TBA) Method for Monitoring Lipid Oxidation in Fish. E.U. Journal of Fisheries \& Aquatic Sciences, 2006; 23(3-4): 331-334.

[14] Suzuki, T. Fish and Krill Protein: Processing Technology. Applied Science Publishers Ltd., London. 1981.

[15] Juemanee, P., K. Kijroongrojana, W. Usawakesmanee, W. Posri. Juiciness Improvement of Frozen Battered Shrimp Burger Using Modified Tapioca Starch, Sodium Alginate, and Iota-Carrageenan. Songklanakarin J. Sci. Technol. 2009; 31(5): 491-500.

[16] Juárez, M., N. Aldai, Ó. LópezCampos, M. E. R. Dugan, B. Uttaro, J. L. Aalbus. Beef Texture and Juiciness in Handbook of Meat and Meat Processing ed. by Y. H. Yui, CRC Press. 2012. 